Justrya Czaja

Instytut Filmu, Mediów i Sztuki Audiowizualnych Uniwersytet im. Adama Mickiewicza w Poznaniu
Images

vol. XXX/no. 39

Poznań 2021

ISSN 1731-450x

\title{
W poszukiwaniu hierofanii - o filmie Góra Sulejmana Jelizawiety Stiszowej
}

\begin{abstract}
Czaja Justyna, W poszukiwaniu hierofanii - o filmie Góra Sulejmana Jelizawiety Stiszowej [In search of a hierophany: on Elizaveta Stishova's Suleiman Mountain]. "Images" vol. XXX, no. 39. Poznań 2021. Adam Mickiewicz University Press. Pp. 201-216. ISSN 1731-450X. DOI 10.14746/i.2021.39.10

The subject of the article is Elizaveta Stishova's film Suleiman Mountain, the action of which focuses on the Kyrgyz mountain, surrounded by religious veneration. The title place is treated as a spatial hierophany, that is, according to Mircea Eliade's concept, a place where and through which the sacred is revealed. The text will analyze the film's space-time and its symbolic dimension, and the characters' relations with the title place, especially the relationship between women and the mountain and its mythical character.
\end{abstract}

KeYworDs: Suleiman Mountain, Elizaveta Stishova, sacred mountain, Axis mundi, hierophany, shamanism, Mircea Eliade, sacred, profane

O Górze Sulejmana (Sulejman Gora, 2017), zauważonym i docenionym[1] pełnometrażowym debiucie rosyjskiej reżyserki Jelizawiety Stiszowej, w rodzimej prasie pisano jako o filmie, któremu „udało się podbić profesjonalną i zwykłą publiczność od Toronto po Karlowe Wary"[2]. Rosyjski filmoznawca Wiktor Prokofiew, komentując amerykańską recepcję filmu i jego recenzje, napisał:

Zwracano uwagę na wysoki profesjonalizm twórców, precyzyjną realistyczną grę aktorów, ale najczęściej w publikacjach używano słowa „unusual” („niezwykły”, „nietypowy”), odnosząc się do opowiadanej historii, do określenia gatunku, do wyboru miejsca akcji, do metody pracy. Jelizawieta Stiszowa, debiutantka w pełnym metrażu odeszła od aktualnych problemów politycznych i społecznych i nakręciła prostą, ale uniwersalną historię. Reżyserka nie gra z gatunkami, nie spekuluje na materiale etnicznym, nie

[1] Film prezentowany był w Stanach Zjednoczonych na festiwalach w Toronto, San Francisco i Palm Springs. Pokazywano go także między innymi w Hamburgu, Rzymie, Bergen, Bratysławie i Barcelonie. Na Międzynarodowym Festiwalu w Karlowych Warach został nagrodzony Kryształowym Globem główną nagrodą konkursu Wschód Zachodu. Zdobył też kilka azjatyckich nagród (Grand Prix MFF Pignao oraz nagrody FIPRESCI i NETPAC 14. Eurazji). W Rosji premierowy pokaz Góry Sulejmana odbył się w konkursie głównym szóstego festiwalu debiutów „Movement” w Omsku, na którym film otrzymał Grand Prix, nagrodą za najlepszą rolę kobiecą uhonorowano Perizat Ermanbetovą.

[2] W. Prokofiew, „Suliejman Gora” - oswieżajuścieje postpostimperskoje road-movie iz Kirgizii, „Cinema Art", 2018, nr 11/12, <https://kinoart.ru/reviews/ suleyman-gora-osvezhayuschee-postpostimperskoe-road-muvi-iz-kirgizii>, dostęp: 2.03.2021. 
posługuje się stereotypem „kina narodowego”, co najwyraźniej robi wrażenie na szacownych kolegach na festiwalowych pokazach[3].

Trudno nie zgodzić się z trafnością tych słów. Prostota, uniwersalizm opowiedzianej historii pozwalają na uniknięcie epatowania „egzotyczną kirgiskością”, ornamentacyjną folklorystycznością, sprowadzonym do roli wizualnej atrakcji szamanizmem. Wspomniana "niezwykłość" w kontekście miejsca akcji i opowiedzianej historii odsyła do obecnej w filmie tajemnicy, za którą skryte to, co metafizyczne, transcendentne, a czego znakiem w filmie staje się tytułowa kirgiska góra, którą potraktować można jako przestrzenną hierofanię.

W filmie Stiszowej wyjątkowość uważanej za święte miejsce Góry Sulejmana - wyznaczającej ekranową czasoprzestrzeń, wpływającej na relacje między bohaterami - uniwersalizowana jest poprzez silne powiązanie jej statusu i roli społeczno-kulturowo-religijnej z kobiecością, pierwiastkiem żeńskim, z mitami chtonicznymi. Analizując film, warto przywołać koncepcje religioznawcze Mircei Eliadego, szczególnie operacyjne w tym kontekście ze względu na ich uniwersalizujący charakter. Eliade, przedmiotem badań czyniąc wierzenia, mitologie, systemy religijne i obrzędy różnych kręgów cywilizacyjnych, pisze bowiem o istocie doświadczenia religijnego, bada morfologię religii, poszukując elementów wspólnych, struktur opartych na analogiach, zbieżnościach. Wprowadzone przez niego pojęcie hierofaniczności będzie też kluczowe dla dalszych rozważań o Górze Sulejmana. Eliade używa go „dla określenia aktu przejawiania się sacrum”[4], podkreślając jednocześnie jego neutralność i uniwersalność:

Termin ten jest dogodny, nie implikuje bowiem żadnych dodatkowych uściśleń: wyraża tylko to, co zawarte jest w jego treści etymologicznej, a mianowicie, że ukazuje nam się, że nam się objawia coś świętego. Można by powiedzieć, że na historię religii - od najelementarniejszych do najwyższych - składa się znaczna ilość hierofanii, objawień, w których wyrażały się rzeczywistości sakralne. [...] W płaszczyźnie strukturalnej stajemy wobec tego samego tajemniczego aktu: objawienia się czegoś „całkiem innego” rzeczywistości, która nie przynależy do naszego świata - w przedmiotach stanowiących integralną część tego świata "przyrodzonego", „laickiego”[5].

Rozpoznania te wydają się szczególnie istotne ze względu na religijno-kulturową palimpsestowość filmu Stiszowej związaną ze specyfiką miejsca, w którym osadzona jest ekranowa akcja. Przedstawiając losy filmowych bohaterów, reżyserka dotyka również kwestii związanych z „piętrową" konstrukcją kirgiskiej religijności i obrzędowości, wynikającą z przemieszania się elementów islamu oraz wierzeń, praktyk religijnych z okresu przedmuzułmańskiego, takich jak tengrianizm czy szamanizm, które odradzają się w czasach współczesnych. Nie wolno też zapominać o sowieckim etapie historii Kirgistanu, przymusowej

[3] Ibidem. Wszystkie cytowane rosyjskojęzyczne teksty w tłumaczeniu autorki artykułu.
[4] M. Eliade, Sacrum, mit, historia, przel. A. Tatarkiewicz, Warszawa 1974, s. 166.

[5] Ibidem, s. 166-167. 
ateizacji, próbie zastąpienia wszelkich przejawów religijności ideologią komunistyczną. Dodatkowo spojrzenie na kirgiską religię, kulturę jest spojrzeniem kogoś z zewnątrz, z innego kręgu kulturowego - reżyserki Rosjanki, urodzonej i mieszkającej na co dzień w Moskwie.

Wątki, które złożyły się na fabułę filmu Góra Sulejmana, obrazy, które widzowie oglądają na ekranie, pojawiały się stopniowo, podczas kolejnych spotkań reżyserki z kirgiską kulturą, obyczajowością[6]. Wcześniej Stiszowa zrealizowała w Kirgistanie swój film dyplomowy Mewa (Czajka, 2012), którego bohaterem był stary Kirgiz - wiejski nauczyciel rosyjskiego rywalizujący z młodym Turkiem uczącym swojego ojczystego języka kirgiskie dzieci. Barwne tureckie stroje, narodowa muzyka i rozdawane $\mathrm{w}$ trakcie lekcji tureckie słodycze przyciągają uczniów, wyraźnie zafascynowanych taką wersją tureckości. Starając się rozbudzić zainteresowanie dzieci tym, co rosyjskie (w imaginacyjnej scenie bohater uczestniczy w rozmowie z Czechowem, Dostojewskim, Tołstojem i Gogolem, czuje się odpowiedzialny za przekazywanie kolejnym pokoleniom rosyjskiej spuścizny kulturalnej, którą traktuje jako część wspólnej historii), zdesperowany stary rusycysta ima się różnych sposobów, zaczynając od przekupstwa, by w końcu zwrócić się w kierunku teatru i klasyki rosyjskiego dramatu i zachęcić uczniów do wystawienia spektaklu na podstawie sztuki Czechowa. Reżyserka filmu Jelizawieta Stiszowa i jego scenarzystka Alisa Chmielnickaja przyglądają się współczesnemu Kirgistanowi, „odkrywając przecięcia, skrzyżowania tradycyjnych i najnowszych kodów kulturowych byłej radzieckiej republiki" [7]. Praca nad dyplomowym krótkim metrażem była również okazją do bliższego kontaktu z obyczajowością i mentalnością Kirgizów. Poczynione obserwacje, poznani ludzie stały się inspiracją dla postaci głównych bohaterów i wybranych wątków w Górze Sulejmana[8].

Przed realizacją swojego pełnometrażowego debiutanckiego filmu Stiszowa pracowała również jako drugi reżyser przy filmie historycznym opowiadającym o żyjącej na przełomie XIX i XX wieku władczyni Kirgistanu Kurmandżan-datka (Kurmanżan-datka, 2014), który reżyserował Sadyk Szer-Nijaz. Podczas realizacji ekipa filmowa podróżowała po całym kraju. To właśnie wtedy rosyjska reżyserka zetknęła się z magiczno-leczniczymi praktykami „wybiwanija biesow” $\mathrm{z}$ chorych, uświadomiła sobie, jak bardzo rozpowszechnione są na terenie całego Kirgistanu, jak wielu ludzi z nich korzysta, pokładając w nich większą nadzieję niż w medycynie konwencjonalnej[9]. „Linia szamańska powstała, gdy dowiedzieliśmy się, że połowa kraju chodzi tu do wróżbiarek. Stąd pojawiło się zainteresowanie i poszłam zobaczyć, jak to się odbywa" [10] - wspomina reżyserka. W trakcie pobytu w Oszu

[6] W latach 2010-2013 Stiszowa pracowała w Kirgistanie w Aytysh-Film (Biszkek).

[7] W. Prokofiew, op.cit.

[8] Jelizawieta Stiszowa - o swojem fil'mie, sniatom w Kyrgystanie, <https://www.golosameriki.com/a/ oleg-sulkin-suleiman-mountain-of-elizaveta-stisho$\mathrm{va} / 5046975 . \mathrm{html}>$, dostęp: 1.03.2021.

[9] Wywiad z Jelizawietą Stiszową przeprowadzony 23.02.12021 r. przez autorkę artykułu.

[10] Jelizawieta Stiszowa - o swojem fil'mie... 
Stiszowa obserwowała również fenomen Góry Sulejmana jako miejsca pielgrzymkowego i turystycznego.

Znajdująca się na południu kraju obok miasta Osz góra, nazywana przez Kirgizów Sulejman Too, stanowi centrum religijno-duchowych praktyk mieszkańców Doliny Fergańskiej. Miejsce to odwiedzane jest przez rzesze pielgrzymów, wśród których sporą grupę stanowią kobiety modlące się tu o zdrowie dla siebie i bliskich, o dostatek dla rodziny, o zajście w ciążę. Zachowane petroglify, czyli wyryte naskalne rysunki nazywane saimaluu-tash - „haftowane kamienie” - świadczą o tym, że góra pełniła funkcje sakralne już w czasach starożytnych.

Etymologię nazwy badacze wiążą z postacią żyjącego w XV wieku sułtana Sulejmana Mazi. Wraz z islamizacją tych terenów utrwaliła się jednak muzułmańska legenda tego miejsca, odsyłająca do władcy i proroka Sulejmana (utożsamianego też niekiedy z biblijnym królem Salomonem). Liczne opowieści, zawierające motywy genezyjskie, koncentrują się wokół bytności proroka w tym miejscu. Wyjaśniają, w jaki sposób powstała sama góra, pobliskie jezioro, rzeka czy kanały, odwołują się do charakterystycznego ukształtowania terenu, a także tłumaczą cudowne, nadprzyrodzone moce tego miejsca. Tego typu przekazy wyjaśniają boskość, świętość przestrzeni uznawanej za hierofanię, legitymizują jej sakralny charakter poprzez przywołanie postaci świętego męża, elementów traktowanych jako ślady, świadectwa jego bytności, artefaktów uważanych za dzieło jego rąk lub myśli. Jak zauważył Mircea Eliade, to nie człowiek wybiera miejsce sakralne, on może je jedynie odnaleźć, odczytując znaki wskazujące, „uzyskuje objawienie się świętego miejsca" [11]. Rumuński religioznawca, pisząc o hierofanii, zwraca uwagę na fakt, że coś „staje się przedmiotem sakralnym o tyle, o ile wciela (tzn. objawia) coś innego, coś różnego od siebie”, przedmiot „staje się hierofanią dopiero wtedy, gdy przestaje być zwykłym przedmiotem świeckim i przybiera nowe «wymiary», wymiary sakralności”[12].

Według jednej z legend Sulejman, któremu służyły ifryty i dżiny, przyleciał na nich do Doliny Fergańskiej i podczas odpoczynku usiadł na górze (do dziś w skale zachowały się odciski jego ciała). Rozpościerający się stąd widok zachwycił go, zauważył jednak, że miejsce to pozbawione jest wody. Wybudował więc meczet $i$, modląc się w nim, poprosił Allaha o wodę. Tak powstała rzeka Ak-Burra oraz kanał Dżanat-Aryk uważany za święty.

Inna wersja legendy mówi o tym, że to Kara-chan poprosił Sulejmana o wodę dla mieszkańców miasta Osz. Prorok rozkazał więc dżinom i dewom wykopać w ciągu jednej nocy kanał nawadniający, $\mathrm{z}$ wydobytej ziemi usypały one wzniesienie, na którym ustawiony został tron proroka (stąd góra nazywana jest też niekiedy Tronem Sulejmana). Inne podania mówią, że na rozkaz swego władcy dżiny wykopały jezioro Aq-ko'l i rzekę Ak-Burrę. 
Na samej górze, w miejscu, w którym prorok czytał namaz (rytualną muzułmańską modlitwę), zachowały się odciski jego kolan, stąd też odczytywanej tu modlitwie przypisuje się moc oczyszczającą. W miejscu, w którym odpoczywał oparty o skałę, do dziś pozostały odciski jego pleców - wierzy się, że ześlizgnięcie się stąd na plecach wyleczy u chorego bóle kręgosłupa. W innej części góry znajdują się zagłębienia będące śladami stóp proroka. Tron Sulejmana (Sighalczik-Tasz, czyli Wyślizgany Kamień), na którym siadywał święty mąż, ma również niezwykłą moc (wierni wierzą, że pełzające na brzuchu kobiety mogą uleczyć bezpłodność, osoby ześlizgujące się na plecach pozbędą się natomiast bólów kręgosłupa, problemów ortopedycznych). Na górze znajdują się również dwa miejsca, w których Sulejman obmywał swoje ciało (zanurzenie głowy w zebranej tam wodzie leczy wszelkie dolegliwości związane z tą częścią ciała). W miejscu, w którym odłożył czytany Koran, pozostała zamieniona w kamień otwarta księga z odciskami palców proroka, który wraz z aniołami odpłynął łodzią do Mekki. Niezwykła moc przypisywana jest też innym fragmentom góry, takim jak choćby kamień Beszik-Tasz, czyli Kamienna Kołyska, przy którym kobiety modlą się o zajście w ciążę, o dar macierzyństwa[13].

Przywołane elementy pełnią funkcję obecnych w wielu wierzeniach przedmiotów hirofanicznych. Kamień, góra traktowane są jako emanacja sacrum. Jak zauważa Eliade: „Kamienie kultowe są znakami zawsze wyrażają rzeczywistość transcendentną. Począwszy od elementarnej hierofanii, wyobrażanej przez niektóre kamienie i głazy, których trwałość, twardość i majestat wprawia w podziw umysł ludzki, aż po symbolikę omfaliczną i meteoryczną, kamienie kultowe nieustannie oznaczają coś, co przekracza los człowieka" [14]. Przypisane zostają im niezwykłe właściwości, moc, stają się więc często elementem obrzędowych praktyk kultywowanych przez różne społeczności opisywane w pracach rumuńskiego religioznawcy: „Zwyczaj zwany "poślizgiem» jest dobrze znany: aby mieć dzieci, młode kobiety ześlizgują się z poświęconego kamienia [...]. Inny obrzędowy zwyczaj, jeszcze bardziej rozpowszechniony, polega na «tarciu»: tarcie jest praktykowane w celach zdrowotnych, ale głównie przez kobiety niepłodne"[15].

Według innej z legend góra była miejscem śmierci Sulejmana, który został zamordowany na jej szczycie „a jego wierni słudzy, czarne psy, wypiły jego krew i zjadły ciało", w czym upatrywać można odwołań do zwyczajów pogrzebowych zoroastrian, „niewykluczone, zresztą, że liczne półki skalne mogły kiedyś służyć jako odpowiedniki zaratusztriańskich wież milczenia”[16]. Istnieją zresztą podania, które wskazują górę jako miejsce, w którym przebywał, pędząc pustelnicze życie, Zaratustra - perski kapłan, prorok i religijny reformator wędrujący po świecie w poszukiwaniu prawdy i objawienia. Góra Sulejmana

[13] M. Łabenda, Dolina Fergańska w czasach islamu, Warszawa 2016, s. 8 o.

[14] M. Eliade, Traktat o historii religii..., s. 228.
[15] Ibidem, s. 217-218.

[16] M. Łabenda, op.cit., s. 8 o. 
tratowana była jako święta jeszcze przed upowszechnieniem się na tych terenach islamu, stanowiła miejsce kultu wyznawców wielu religii: zaratusztrianizmu, manicheizmu, tengrianizmu.

Obraz góry, jej symbolika miejsca mocy pojawiały się już w pierwszej wersji filmowego scenariusza Jelizawiety Stiszowej i Alisy Chmielnickiej, który diametralnie różni się od wersji ekranowej. Pierwotny zarys fabuły przedstawiał historię kobiety alkoholiczki i jej małego syna. Chłopiec zmusza matkę do wyprawy na Górę Sulejmana, wierząc, że moc tego miejsca uleczy ją i pozwoli zerwać z wyniszczającym nałogiem. Podczas wspinaczki dziecko ginie. W odczuciu Stiszowej historia ta była jednak zbyt dramatyczna, reżyserka chciała nasycić fabułę elementami komicznymi, tragikomicznymi[17].

W ostatecznej wersji scenariusza Góry Sulejmana, podobnie jak w samym filmie, przywołane w tytule miejsce również odgrywa kluczową rolę - wizualnego leitmotivu, miejsca akcji, w którym następują dramatyczne spięcia między bohaterami, głównego elementu filmowej czasoprzestrzeni obdarzonego sensami symbolicznymi, naddanymi. Fabuła filmu przedstawia splecione ze sobą losy czworga bohaterów: 50-letniego Karabasa[18] (Asset Imangaliew), który decyduje się na powrót do swojej żony Żapary (Perizat Ermanbetowa), po tym, gdy kobiecie udaje się odnaleźć ich zaginionego kilkuletniego syna Ułuka (Daniel Dayirbekow). Mężczyzna przywozi z sobą młodą dziewczynę Turgunbubu (Turgunai Erikenbekowa), którą w międzyczasie poślubił i która oczekuje jego dziecka. Obie żony rywalizują między sobą o Karabasa. Cudowne odnalezienie Ułuka w finale filmu okazuje się mistyfikacją zdesperowanej Żapary, która próbuje odzyskać męża. Piątym bohaterem staje się tytułowe miejsce - Góra Sulejmana - z którą związane będą losy postaci. Przestrzeń powiązana zostaje z filmowymi protagonistami - staje się miejscem, w którym opadają wszelkie maski, obnażone zostają kłamstwa, słabości, skrywane pragnienia. To właśnie tu rozgrywa się jedna z pierwszych scen filmu i jedna z ostatnich - kulminacyjna. Ekranowy czas pomiędzy owymi punktami dramaturgicznymi wyznaczają kolejne epizody wpisane w motyw podróży - chaotycznego wirowania i krążenia wokół góry zdezelowanym samochodem ciężarowym, którym poruszają się bohaterowie.

Związek miejsca akcji i postaci najwyraźniejszy, najłatwiej uchwytny jest w przypadku Żapary. Wiąże się bowiem ściśle z jej profesją, statusem. Żapara, określana przydomkiem Sulejmańska, to popularna uzdrowicielka, która na zboczach góry odprawia regularnie rytuały

[17] Wywiad z Jelizawietą Stiszową...

[18] Przydomek mężczyzny, który potraktować można jako nomen omen, odsyła do negatywnego bohatera Karabasa Barabasa - demonicznego właściciela teatru lalkowego w popularnej książce dla dzieci Złoty kluczyk, czyli niezwykłe przygody pajacyka Buratino Aleksieja Tołstoja, w języku tureckim słowo „kara” oznacza „czarny”, „ciemny”, „czerń”. Filmowy protagonista w niczym nie przypomina mitycznego bohatera, silnego i odważnego, choć tak, przed pierwszym spotkaniem dziecka z ojcem, opisuje go Ułukowi Żapara, śpiewając fragmenty narodowego eposu Manas, przedstawiającego życie i czyny legendarnego przodka Kirgizów. W rzeczywistości to hazardzista, oszust i złodziej, mężczyzna brutalny, gwałtowny, nieodpowiedzialny. 
w kobiecych kręgach - komunikuje się ze światem duchów, uzdrawia, uwalnia zamknięte w kobietach piękno i siłę, sprzedaje lecznicze zioła. Handluje również cudowną gliną z Góry Sulejmana. Bohaterka swobodnie wkracza w świętą przestrzeń, wykorzystuje jej moc do swych obrzędów i praktyk. Wykorzystuje ją jednak także do swoich manipulacji. To na cudowną interwencję góry powołuje się, tłumacząc mężowi rzekome nagłe odnalezienie zaginionego syna Ułuka: „Karabas, Góra Sulejmana wysłuchała nasze modlitwy”. To autorytet świętego miejsca przywoływany jest, by oszukać napotkanych po drodze mężczyzn sprzedać im cudowne medykamenty i zdobyć pieniądze na naprawę koła w samochodzie. Z górą związane są życie bohaterki i jej śmierć. Postać ta może być potraktowana jako medium hierofaniczności, przenosi w sferę codzienności porządek myślenia religijnego, umożliwia innym kontakt $\mathrm{z}$ tym, co przynależne do sfery sacrum.

W przestrzeń świętej góry wkracza także Turgenbubu, młoda żona Karabasa. W jednej z początkowych scen, płacząc, podąża za Żaparą - niesie różne przedmioty, które ta wykorzystuje podczas swoich leczniczo-magicznych rytuałów, w milczeniu przyjmuje jej słowa, że powinna się pogodzić z pozycją drugiej żony. Dziewczyna w otoczonym religijnym kultem miejscu podporządkowuje się autorytetowi wróżbiarki, choć po jego opuszczeniu okazuje wrogość. W scenie finałowej Turgenbubu nie wejdzie już na górę, nie uzna autorytetu Żapary, podejmie z nią walkę i przegra. Dla Turgenbubu odkrycie prawdy o pochodzeniu Ułuka i zdemaskowanie kłamstwa Żapary stają się szansą na pozbycie się rywalki, zdobycie na wyłączność Karabasa. Tak się jednak nie dzieje. Mężczyzna, któremu u podnóża góry młoda żona wykrzyczy w gniewie: "Całe twoje życie zbudowane jest na jej kłamstwie”, brutalnie ją odtrąci.

Ułuk, zgodnie z reżyserską intencją jedyny pozytywny, mogący budzić sympatię widzów bohater, traktuje świętą górę jako miejsce mocy i schronienie. To tu ucieka przed ojcem, który swą wybuchowością i skłonnością do przemocy wzbudza w nim lęk, to tu zanosi swoje modlitwy do Sulejmana, prosząc go o pomoc, o ułożenie skomplikowanych relacji między dorosłymi, wśród których znalazł się po opuszczeniu domu dziecka. Chłopiec towarzyszy również Żaparze w jej wędrówce na górę w końcowej scenie filmu, stając się świadkiem jej śmierci.

Karabas ani razu nie wspina się wraz z kobietami na wzgórze. $\mathrm{W}$ początkowej scenie zostaje na dole razem $\mathrm{z}$ kilkoma spotkanymi mężczyznami przy ciężarówce. W końcowej również zatrzymuje się u stóp góry. Dopiero po odkryciu oszustwa żony, wzburzony, wbiega na wzniesienie. „Jak śmiałaś, suko?! Najświętsze” - jedyne wypowiedziane przez bohatera zdanie brzmi dwuznacznie. Do czego odnosi się słowo "najświętsze”? Być może do ojcostwa, rodziny jako tego, co otoczone szczególną, największą czcią, a czego pierwsza żona nie uszanowała, okłamując i Ułuka, że jest ich dzieckiem, i Karabasa, że odnalazła jego zaginionego syna. Wtargnięcie mężczyzny w świętą przestrzeń kończy się tragicznie, doprowadza do śmierci Żapary. W filmie Stiszowej Góra 
Sulejmana przedstawiana jest bowiem jako góra kobiet, to, co duchowe, mistyczne identyfikowane jest z pierwiastkiem żeńskim, to kobiety szukają w tym miejscu pomocy i to kobiety odprawiają szamańskie rytuały. Wyraźne cechy praktyk szamańskich ma to, czym na zboczach Góry Sulejmana trudni się Żapara (w scenie odwiedzin Karabasa w rodzinnym domu wrogo nastawiona wobec synowej matka mężczyzny pyta go, dlaczego jego żona udaje na bazarze szamankę): kontaktowanie się ze światem duchów, wykrywanie chorób i ich leczenie, zdejmowanie uroków, wypędzanie złych duchów, odgadywanie przyszłości, którym towarzyszą rytualny trans, okadzanie ziołami.

Interesująca w tym kontekście jest scena rozgrywająca się w willi mera Oszu. Zrozpaczona małżonka wzywa Żaparę, bojąc się o własnego męża, którego matka zapadła w śpiączkę, zawiodły bowiem wszelkie konwencjonalne metody[19]: lekarze nie potrafią pomóc umierającej teściowej, a psycholog zdesperowanemu mężowi kobiety, obwiniającemu się o to, że opuścił chorą matkę. Przed jej śmiercią musi poprosić ją o wybaczenie. Żapara przystępuje do swoich magicznych praktyk. W transie obwąchuje i „oświstuje” chorą - ryczy i gwiżdże, wydmuchując ustami powietrze, (w szamanizmie oddechowi, podobnie jak ślinie, przypisywana jest życiodajna, duchowa moc), siada na niej okrakiem, unosi jej bezwładne ciało, szarpie nieprzytomną i zaczyna okładać ją biczem[20]. Aby nasycić sceny realizmem, grająca Żaparę Perizat Ermanbetowa konsultowała się z kobietami, które uzdrawiają i wróżą, uczestniczyła w różnych magiczno-leczniczych seansach, przyglądali im się również inni członkowie ekipy filmowej. W scenie rytuału, podczas którego Żapara próbuje poznać przyszłość - odkryć dalsze losy Turgenbubu i swoje - wystąpiły dwie autentyczne kirgiskie wróżbiarki.

[19] W opisanej scenie znaczące są elementy scenografii i rekwizyty. W pokoju chorej matki mera na stojącej przy łóżku szafce widoczne są poustawiane tam liczne leki. Obok znajduje się także aparatura podtrzymująca i monitorująca funkcje życiowe.

Elementy te stanowią kontrastowe zestawienie ze sposobami leczenia, które stosuje Żapara. Dodatkowo jej znachorskim praktykom przygląda się z przerażeniem zatrudniona do opieki nad chorą młoda pielęgniarka. $\mathrm{W}$ jednym $\mathrm{z}$ wywiadów zapytana o wierzenia mające jedynie pośredni związek $\mathrm{z}$ oficjalną religią, jaką w Kirgistanie jest islam, a determinujące życie codzienne filmowych bohaterów, Stiszowa odpowiedziała: „Tutaj to bardzo rozpowszechnione, praktycznie w każdej wiosce. Korzenie tengrianizmu są bardzo silne (tengrianizm to przedislamska religia koczowników turecko-mongolskich z kultem Tengri, deifikowanego nieba). Oprócz tego medycyna głównego nurtu jest tak zła, że ludzie wolą iść do wróżbiarki niż do lekarza”. Jelizawieta Stiszowa - o swojem fil'mie...
[20] Węgierski turkolog Dávid Kara Somfai i Mihály Hoppál, autor książki Szamani euroazjatyccy, obserwowali obrzędy kirgiskich szamanów (w szczególności unikalny mistyczny taniec Tałma bij) w odciętej od świata górskiej wsi Tegirmeti w Chinach: „Znachor zaprasza do tańca chorych, dręczonych przez szatany/złe duchy lub obłąkanych, już opętanych, prowadzi ich wokół arkanu, zadaje ciosy, bije biczem, czasem powaliwszy na ziemię, depcze ich i w ten sposób wypędza złe duchy. Szaman w transie otwiera drogę do górnego świata i stamtąd niejako przynosi sposoby leczenia. Do górnego świata dusza znachora podróżuje przez «tunduk» jurty. Jurta to symbol granatowego nieba, symbol Tengira - Głównego Boga koczowników". Dż. Dżusupdżan, Dalekoje echo szamana ili kamtanije po-kyrgyzskij, <https://rus.azattyk.org/a/kyrgyzstan_kamlanie_jusupjan/24361279. html>, dostęp: 5.03.2021. W odprawianych przez Żaparę rytuałach odnaleźć można podobne elementy. 
Na zboczach góry kobiety gromadzą się w niewielkich kręgach, odprawiają magiczne rytuały, którym przewodzi Żapara, uzdrawiając, przepędzając złe siły. W innej ze scen święte duchy Góry Sulejmana wzywają wróżbiarki, które wieszczą. W rzeczywistości pozafilmowej miejsce to istotnie odwiedzane jest często przez pielgrzymujące muzułmanki, wśród nich te, które starają się zajść w ciążę, leczą bezpłodność. Sakralne znaczenie przypisywane znajdującym się tu jaskiniom i samemu wzniesieniu pochodzą jednak jeszcze z czasów przedislamskich. Góra była pradawnym miejsce kultu bogini Umaj, uważanej za najstarsze żeńskie bóstwo koczowników, kojarzonej ze wzrostem, dojrzewaniem, płodnością natury[21]. Jej opiece powierzano noworodki i małe dzieci a także kobiety, zwłaszcza rodzące. Umaj[22] - bogini ziemi, podobnie jak jej mąż Tengri - pan nieba[23], czczona była przez ludy tureckie i mongolskie praktykujące szamanizm.

Etymologia imienia bóstwa odsyła do łona matki, macicy, odciętej pępowiny, bogini kojarzona jest $\mathrm{z}$ tym, co zlokalizowane w dole z ziemią, jaskinią, szczeliną symbolizującymi macierzyńskie łono[24]. Umaj, podobnie jak obecne w wielu mitologiach bóstwa telluryczne i chtoniczne - związane z ziemią i płodnością - utożsamiana jest $\mathrm{z}$ zasadą kobiecą, pierwiastkiem żeńskim. Oparty na analogii zdolności „rodzenia”, owocowania, urodzajności gleby do kobiecej płodności, wydania na świat dziecka i odwołujący się do triady ziemia - kobieta płodność obraz Matki-Ziemi, Terra Mater, Tellus Mater, ma charakter archetypiczny, występuje w wielu wierzeniach, mitach i obrzędach na całym świecie[25]. Jak zauważa Eliade:

Kobieta mistycznie związana jest z ziemią; wydanie na świat dziecka okazuje się wariantem - na skalę ludzką - płodności tellurycznej. Wszelkie doświadczenia religijne, związane z płodnością i narodzinami, mają strukturę kosmiczną. Sakralność kobiety związana jest ze świętością ziemi. Płodność kobiety ma wzorzec kosmiczny, jakim jest płodność Terra Mater $[\ldots][\mathbf{2 6}]$.

Jednym z elementów związanych z tym kultem są jaskinie, kojarzone z żeńskimi narządami rozrodczymi, macicą i utożsamiane

[21] Driewnietjurskije mify. Po knigie O. Markowoj i K. Żanabajewa „Zołotaja kolybiel” - Tengri i Umaj $<$ http://bibliotekar.kz/kazahskaja-literatura-hrestomatija-za-6-/tengri-i-umai.html>, dostęp: 7.03.2021.

[22] Kult bogini Umaj praktykowany był między innymi przez Kirgizów, Kazachów, Buriatów, Mongołów, Tatarów.

[23] Tengri i Umaj, pierwsi bogowie, są bohaterami mitu kosmogonicznego i genezyjskiego - po wielkiej katastrofie, $\mathrm{z}$ wielkiego chaosu wyłaniają się błękitne niebo i żyzna ziemia, między którymi pojawiła się ludzkość. Pierwsi bogowie stanowią personifikację żywiołów, deifikowane niebo i ziemię czczone przez tureckie ludy koczownicze. Zob. Driewnietjurskije mify... Eliade zwraca uwagę na uniwersalność mitu kosmogonicznego, w którym występuje hierogamia między bóstwem żeńskim Ziemią a bóstwem męskim Niebem, na jego obecność wśród społeczności pierwotnych należących do różnych kręgów kulturowych. Zob. M. Eliade, Sacrum, mit, historia..., s. 154, idem, Traktat o historii religii..., s. 236-237.

[24] D.A. Nikołajewa, Żenskoje bożestwo w tradicionnoj kulturie buriat priedbajkalia, „Izwiestija Rossijskogo gosudarstwiennogo pedagogiczeskogo uniwersiteta imienija A.I. Gierciena" 2010, nr 123, s. 247. [25] Zob. M. Eliade, Traktat o historii religii..., s. 235-258, idem, Sacrum, mit, historia ..., s. 149-155. [26] Idem, Sacrum, mit, historia..., s. 153. 
z łonem Matki-Ziemi, z miejscem, w którym skupiona jest życiodajna siła ziemi[27].

Wątek macierzyństwa, kobiecej płodności, odgrywa istotną rolę w kontekście filmowej historii. Żapara próbuje odzyskać męża, udając matkę Ułuka (poszukiwania chłopca, jego odnalezienie pełnią funkcję dramaturgiczną, istotną dla zawiązania akcji, jej przebiegu i filmowego finału, wpływają na losy wszystkich bohaterów). Druga żona Karabasa, Turgunbubu, spodziewa się dziecka. Ciążę wykorzystuje w rywalizacji z pierwszą żoną jako coś, co ma jej zapewnić oddanie i uwagę Karabasa. Poronienie, utrata dziecka sprawiają, że mąż odwraca się od niej. Podczas kłótni w ciężarówce zaparkowanej u stóp góry poniża ją, deprecjonuje jako kobietę poprzez porównanie do Żapary i afirmację kobiety-matki, tej, która potrafiła urodzić syna. Święta góra, z jej mocą inicjowania życia, obdarzania płodnością, zsyłania błogosławieństw, siłą sprawczą włącza losy trojga bohaterów w mistyczny krąg życia.

Przez taki właśnie pryzmat spojrzeć można również na zakończenie filmu i tragiczną śmierć Żapary. Wiktor Prokofiew pisze o dramatycznym finale: „Góra Sulejmana, która była dla Żapary miejscem siły, mocy, zdradza ją"[28]. Czy jednak rzeczywiście tylko w ten sposób interpretować należy zakończenie? Czy w planie symbolicznym ofiara życia złożona na świętej górze nie ma mocy odkupienia i oczyszczenia? Kobieta zapłaci za swoje kłamstwo życiem, jej śmierć może być jednak również impulsem do zmiany dla mężczyzny. Żapara ginie na zboczach świętej góry, ale Karabas być może doświadczy transformującej mocy góry - poprzez wkroczenie w jej przestrzeń, śmierć żony, poniesioną przez nią ofiarę życia. Przemiana, która może w nim nastąpić, wpływa na relację z synem. To swoista inicjacja w ojcostwo, wiek męskość rozumiany jako dojrzałość i odpowiedzialność. W scenie zamykającej film Karabas szuka pojednania $\mathrm{z}$ dzieckiem (finał nie obiecuje jednak widzowi łatwego happy endu, zakończenie pozostaje bowiem otwarte).

Dla każdego z bohaterów wstępowanie na górę ma wymiar symboliczny, stanowi moment transgresji. Uświęcona przestrzeń wyznacza granicę pomiędzy sacrum i profanum, to, co dzieje się w jej obrębie, odwraca porządek rzeczy, jej przekroczenie w przypadku każdej z postaci pociąga za sobą inne konsekwencje, w odmienny sposób wpływa na bohaterów, na ich losy, działania, decyzje.

Tytułowa góra stanowi w filmie najistotniejszy element konstrukcji ekranowej przestrzeni. To wokół niej krążą enerdowską ciężarówką bohaterowie, oddalają się od niej jedynie po to, by znów powrócić. Nieustannie przyciąga ich ku sobie, stanowi centrum ich świata, wyznacza oś, wokół której orbitują. Staje się także milczącym świadkiem ich losów, współuczestnikiem ich dramatów. Nieprzypadkowo rosyjski recenzent Wiktor Prokofiew napisał, że góra jest „epickim bohaterem”[29] utworu. Reżyserka Jelizawieta Stiszowa i operator filmu Tudor Władimir 
Panduru, filmując owego „epickiego bohatera”, starali się znaleźć różne punkty widzenia, które byłyby interesujące. Niektóre ujęcia prezentują ją w całej okazałości, w innych pokazywane są w bliższych planach jej wybrane fragmenty - zbocza, skały, jaskinia, w jeszcze innych staje się elementem tła, w interesujący sposób filmowanego z perspektywy dziecięcego pokoju w sierocińcu Ułuka czy przez niewielkie okienko skrzyni ładunkowej ciężarówki, w której na powrót Karabasa czekają dwie kobiety i chłopiec. Twórcy filmu próbowali pokazać tytułowe miejsce $\mathrm{z}$ różnych stron, o różnych porach roku, $\mathrm{w}$ taki sposób, by jednak nie tracić go z pola widzenia, by ciągle stanowiło centralny punkt ekranowej przestrzeni[30].

Góra odgrywa również istotną rolę w konstrukcji czasu ekranowego. Jego upływ w filmie Stiszowej zostaje widzowi jedynie zasygnalizowany, często właśnie za pomocą zmieniającego się pejzażu związanego z porami dnia i porami roku. Wybrane ujęcia prezentujące górę w świetle dnia, o zmierzchu, pokrytą śniegiem, na tle zieleniących się traw wyznaczają temporalną ciągłość opowieści, wprowadzają również do filmu element metafizyki. Upływ czasu odmierzany przez rytm natury, cykliczność pór roku kojarzą się zwykle z mitem i charakterystyczną dla niego holistyczną strukturą czasu (ów symboliczny wymiar czasu dodatkowo podkreślony zostaje przez obecny w filmie motyw podróży - drogi po okręgu, która rozpoczyna się i kończy w tym samym miejscu). Wznoszące się nad miastem i płaskim krajobrazem pięć skalistych wierzchołków obrazuje potęgę przyrody, jej surowe piękno, tajemniczość. Podkreślają to statyczne ujęcia utrzymanych w zimnych barwach skał i nieba.

Widać to choćby w scenie modlitwy Ułuka, po tym, jak postawiony z Karabasem, ucieka od nieznanego ojca, który budzi w nim lęk, i wbiega po wąskiej ścieżce w górę, by tu prosić o pomoc i opiekę Sulejmana (filmowany w planach dalekich rozległy pejzaż podkreśla zagubienie w przestrzeni bohatera, jego niewielką posturę). W kolejnym ujęciu ukazany na tle szarych nagich skał chłopiec klęczy, zamyka oczy, w modlitewnym geście unosi dłonie. Na szczycie jaskini, w której się schronił, znajduje się otwór - „okno nieba” - przez który widać zimny, przezroczysty błękit. W scenie tej dodatkowo przywołana jest symbolika jaskini jako świętego schronienia, powrotu do bezpiecznego matczynego łona - co odzwierciedla stosunek chłopca do Żapary „bezpiecznej” matki, do której lgnie, i Karabasa, budzącego lęk, obcego ojca. Kruchość, bezbronność małego dziecka skontrastowane zostają $\mathrm{z}$ potęgą natury. Monumentalna góra trwa, odwieczna, niewzruszona, obojętna wobec ludzkich dramatów, które rozgrywają się tuż obok.

W filmie zrezygnowano całkowicie z muzyki i dźwięków niediegetycznych. Rozgrywającym się w górach scenom towarzyszy często cisza, niekiedy w warstwie audialnej pojawia się odgłosy wiatru czy osypujących się kamieni, innym razem odgłosy modlitw, rytualnych 
śpiewów - wszystko to buduje aurę niesamowitości tego miejsca. Natura, przyroda w filmie pokazywana jest w sposób, który wykracza poza jej materialność, ewokuje tajemnicę, otwiera na to, co niepoznawalne zmysłowo.

Skała objawia człowiekowi coś, co przekracza kruchość ludzkiego sposobu bycia: absolutny sposób istnienia. Jej opór, bezwładność, proporcje i dziwne kształty nie są ludzkie. Są one dowodem obecności czegoś, co olśniewa, przeraża, pociąga i grozi. Widząc wielkość skały, jej twardość, kształty i barwę człowiek natrafia na jakąś rzeczywistość i siłę, które należą do innego świata niż świat niesakralny, świecki, którego część on sam stanowi[31].

Dla osiągnięcia takiego efektu twórcy filmu kreują na ekranie specyficzny obraz tytułowego miejsca, eliminując określone elementy jego rzeczywistego wyglądu. Proponują widzowi subiektywny widok przestrzeni hierofanicznej. Nie pokazują bowiem rozbudowanej „pielgrzymkowo-turystycznej infrastruktury”: znajdujących się na Sulejman Too meczetów i muzeum etnograficznego, zainstalowanych poręczy oraz wybetonowanych ścieżek i schodów ułatwiających odwiedzającym przemieszczanie się, nie pokazują góry jako bardzo popularnego miejsca turystyki pielgrzymkowej tłumnie odwiedzanego przez modlących się i zwiedzających. Tym samym ponad pejzażem realnym ukształtowany zostaje pejzaż mistyczny.

Przywołane w tytule filmu Stiszowej miejsce wprowadza do filmu elementy mistycyzmu i transcendencji, wpisuje się w kulturowo utrwalone wyobrażenie świętych gór, przestrzennych hierofanii. Majestatyczność, posępne piękno, niedostępność gór od najdawniejszych czasów wzbudzały ludzki lęk i szacunek, oddziaływały na wyobraźnię, nic więc dziwnego, że zaczęto przypisywać im dodatkowe znaczenia łączono ze sferą sacrum, z tym, co mistyczne i transcendentne. Uważane za siedzibę bóstw i bogów, za miejsca obdarzone niezwykłą mocą, otoczone czcią i kultem pojawiają się w mitologiach różnych ludów europejskich i orientalnych [32].

Organizacja przestrzeni w filmie Stiszowej z Górą Sulejmana jako centralnym punktem łączącym niebo i ziemię odsyła do obecnego w szamanizmie wyobrażenia Góry Kosmicznej jako Axis Mundi, Osi Kosmicznej, Środka Świata:

Najistotniejszym elementem kosmologii szamańskiej jest łącznik między trzema światami, czyli axis mundi [łac. „oś świata”], oś kosmiczna, symboliczne wyobrażenie kosmosu w postaci pionowej struktury, wokół której zorganizowane są i na której wspierają się poszczególne jego elementy (światy, krainy zaświatowe, ołochy itp.). Oś kosmiczna, symbolizująca organiczną jedność świata, umiejscawiana jest zawsze w centrum i przedstawiana na ogół jako słup (filar, kolumna), góra bądź jako Drzewo Kosmiczne (arbor mundi), a nawet kręgosłup praprzodka. Oś ta opisywana jest w kategoriach drogi prowadzącej do innego świata, pomostu między

[31] M. Eliade, Traktat o historii religii..., s. 212. [32] Zob. M. Eliade, Szamanizm i archaiczne techniki ekstazy, przeł. i wstęp K. Kocjan, oprac. naukowe
J. Tulisow, Warszawa 1994, s. 266-270; A. Szyjewski, Szamanizm, Kraków 2005, s. 183. 
różnymi sferami rzeczywistości (np. niebem, ziemią i piekłem, tym co widzialne i niewidzialne, sacrum i profanum) [33].

„Centralna góra wszechświata, łącząca wszystkie poziomy bytu, wszystkie światy, na której wspiera się sklepienie nieba" [34] w wierzeniach Kirgizów wiąże się z podziałem i wyobrażeniem trzech sfer: Świata Górnego, Dolnego i Środkowego, czyli tego, w którym żyją ludzie. Kształt góry podkreśla jej łączność zarówno z niebem, jak i ziemią, i wpisuje się w wertykalną organizację przestrzeni, stając się pomostem pomiędzy światem ludzi a światem transcendentnym. Kluczową rolę w szamańskich praktykach odgrywa postać szamana jako łącznika między trzema światami, kogoś, kto potrafi odbywać między nimi podróż, komunikować się z duchami. Osoba taka, w Kirgistanie nazywana bübü-bakszy, to jednocześnie znachor, wróżbita i kapłan. Kamłanie, czyli szamańskie rytuały odprawiane w stanie transu, mają na celu kontaktowanie się z duchami, leczenie.

Mircea Eliade, opisując w różnych religiach i wierzeniach przestrzeń, w której manifestuje się to, co sakralne, zauważa: „Tam, gdzie dzięki hierofanii nastąpił przeskok między poziomami, dokonało się także «otwarcie» ku górze (świat boski) i ku dołowi (regiony dolne, świat umarłych). Umożliwiona została łączność między trzema poziomami kosmicznymi: ziemią, niebem, regionami dolnymi"[35]. Jako powtarzający się element pełniący funkcję takiego łącznika - „wszechświatowej kolumny”, „kolumny kosmicznej” „axis mundi” - rumuński religioznawca wskazuje górę. „Taka kolumna kosmiczna musi znajdować się w samym środku świata, gdyż wokół niej rozciąga się całość świata mieszkalnego" [36].

Mamy tu więc do czynienia $\mathrm{z}$ łańcuchem koncepcji religijnych i obrazów kosmologicznych, wiążących się z sobą i artykułujących się w system, który można by nazwać „systemem świata” społeczności tradycyjnych: a) miejsce święte stanowi przerwanie jednorodności przestrzeni; b) symbolem tego przerwania jest otwarcie, które umożliwia przejście $\mathrm{z}$ jednego regionu kosmicznego do innego (z nieba na ziemię i vice versa: $\mathrm{z}$ ziemi do świata niższego); c) łączność z niebem wyraża się przez pewną ilość różnorodnych obrazów, które odnoszą się do axis mundi: słup (por. universalis columna), drabina (por. drabina Jakubowa), góra, drzewo, liana itp.; d) wokoło owej osi kosmicznej rozciąga się świat (to jest „nasz świat”), a więc coś znajduje się „pośrodku”, „u pępka ziemi», ona to jest środkiem świata[37].

Eliade analizuje jakościowe zróżnicowanie przestrzeni, jej heterogeniczność, „rozdarcie”, które pozwala na „ustanowienie świata” poprzez wyodrębnienie „punktów stałych”[38], rozdzielenie sfer sacrum i profanum. Jego zdaniem to właśnie „sacrum pojawiając się ustanawia ontologicznie świat”, „hierofania objawia absolutny «punkt stały», «środek»"[39].

[33] A. Szyjewski, op.cit., s. 180-181.

[34] Ibidem, s. 183.

[35] M. Eliade, Sacrum, mit, historia..., s. 149.

[36] Ibidem.
[37] Ibidem.

[38] Ibidem, s. 143.

[39] Ibidem. 
W filmie Stiszowej takim centrum staje się tytułowa góra, wyznaczająca „środek świata” bohaterów (a poza diegezą, w warstwie metafilmowej, będąca centralnym element kompozycji filmu, kluczowym punktem konstrukcji ekranowej przestrzeni). Przestrzeń góry, związana z tym, co metafizyczne, transcendentne, ze sferą sacrum, skontrastowana zostaje z przestrzeniami „świeckimi”, w których funkcjonują bohaterowie - sierocińcem, bazarami, salką hazardową, punktem naprawy samochodów - miejscami $\mathrm{z}$ porządku profanum. Zgodnie z koncepcją Eliadego to, co świeckie, wiąże się z względnością przestrzeni, brakiem ukierunkowania i punktów stałych „nie ma już «świata», tylko fragmenty świata rozbitego, bezkształtnej masy niezliczonych «miejsc», mniej lub bardziej neutralnych, w których człowiek porusza się rządzony prawami wszelkiej egzystencji, włączonej w społeczeństwo typu przemysłowego" [40]. Owa fragmentaryczność, rozbicie podkreślone zostają w filmie za pomocą struktury dramaturgicznej - fabuła rozpada się na ciąg epizodów, ukazujących bohaterów w różnych miejscach, w różnych przestrzeniach „świata świeckiego”, które wiążą się z ich chaotyczną podróżą donikąd. Pomiędzy nimi, jako wizualny leitmotiv, pojawia się ujęcie góry jako czegoś trwałego, niezmiennego, przedwiecznego.

Organizujący fabułę motyw podróży odbywanej samochodem „wokół góry” w połączeniu z charakterystyczną konstrukcją przestrzeni wyznaczanej przez centralny punkt, czynią z filmu Stiszowej specyficzne kino drogi. Motyw ten nie zostaje sfunkcjonalizowany w sposób typowy dla road movies. Wpisane w niego sensy nie mają nic wspólnego ze spetryfikowanymi elementami cechującymi tę konwencję filmową: dokonywanym przez ekranowych bohaterów samopoznaniem, apoteozą wolności, niezależności, indywidualizmu, idealizowanym doświadczeniem bycia w drodze jako celem i wartością samą w sobie. Bohaterowie Stiszowej w niczym też nie przypominają romantyzowanych zwykle przez kino drogi postaci podróżujących - outsiderów i buntowników poszukujących swego miejsca w świecie, w imię własnej wolności i autentyzmu kontestujących obowiązujące normy i zasady.

Wśród filmowych protagonistów charakterystycznych dla road movies - jak zauważył Adam Wyżyński - dominują dwie grupy: pierwsza $\mathrm{z}$ nich to „ci, którzy wyruszają «dokądś»” bądź "po coś»”, potrafią określić cel swojej podróży, druga natomiast „wałęsa się bez uświadomionego celu lub jest w drodze «od czegoś»”[41]. Do tej właśnie należą protagoniści 
filmu Stiszowej. Ich podróż jest ucieczką przed wierzycielami, okazją do spotkania kolejnych ludzi, których można wykorzystać, oszukać, okraść. Można na nią spojrzeć jak na karykaturalną, groteskową formę koczowniczej kirgiskiej tradycji - bohaterowie przenoszą się z miejsca na miejsce starą enerdowską ciężarówką, w której mieszkają i która staje się współczesnym zamiennikiem i konia, i jurty.

Podróż ekranowych bohaterów pozbawiona jest celu i kierunku rozumianego jako konkretny punkt docelowy, miejsce, do którego chce się dotrzeć, określona destynacja. Zastępuje je chaotyczny ruch oparty na krążeniu wokół tytułowej góry. Ów ruch, jego charakter podkreśla relacje między bohaterami, ich egzystencjalne i emocjonalne zapętlenie, wzajemne uwikłanie, niemożność wyrwania się ze schematyzmu własnych myśli, uczuć, działań...

Góra Sulejmana jako element centralny świata ekranowych bohaterów, filmowej czasoprzestrzeni stanowi punkt przecięcia dwóch porządków przestrzennych - wertykalnego i horyzontalnego. Ten drugi, powiązany z cyrkularnością, mieści w sobie następstwo pór dnia i roku, krążenie samochodem wokół jednego miejsca. Przestrzeń horyzontalna, mimo zewnętrznych pozorów otwarcia, jest przestrzenią zamkniętą - zarówno na poziomie dosłownym, fizycznym, jak i przenośnym, metaforycznym. Bohaterowie są bowiem zamknięci w kabinie ciężarówki-domu, którą podróżują (filmowanie postaci w ciasnym, ograniczonym wnętrzu samochodu, fabularny motyw podróży), są też "zamknięci” w powtarzanych schematach własnych zachowań, dokonywanych wyborów, wreszcie w cyklu życia - narodzin i śmierci (podkreślają to ujęcia przyrody). Jedynie przestrzeń wertykalna pozostaje przestrzenią otwartą. Nieprzypadkowo to, co najważniejsze, dzieje się podczas wkraczania, wstępowania bohaterów na Górę Sulejmana. Przestrzeń hierofaniczna umożliwia „przekroczenie horyzontu”, uwolnienie.

W swej podróży bohaterowie Stiszowej krążą nieustannie wokół góry, która z fatalistyczną siłą przyciąga ich ku sobie, stając się miejscem dramatycznej konfrontacji i bolesnej deziluzji. Łączące ich więzi okazują się pozorne i nietrwałe, oparte są bowiem na egoizmie, fałszu, manipulacji. Jak trafnie zauważył rosyjski recenzent:

Motyw drogi nie tyle prowadzi fabułę filmu, ile formuje znaczenia symboliczne. Bezcelowość i krążenie podróżników stanowią aluzję do zwodniczej drogi, wyobcowania i występnych czynów, które popełniają wciąż od nowa. Ten sojusz po prostu musi się rozpaść, żeby każdy z jego uczestników doszedł do końca drogi - dla kogoś zgubnej, dla kogoś, być może, zbawiennej[42].

I początek, i kres owej drogi wyznacza Góra Sulejmana. Tytułowe miejsce dzielące przestrzeń na sferę sacrum i profanum, podobnie jak podróż, droga bohaterów po okręgu, otwierają film na przenośne odczytania, uniwersalizują jego treść. Czynią z niego metaforę koła życia, w które wpisane są śmierć, ofiara, poszukiwanie, zmiana...

[42] W. Prokofiew, op.cit. 
Clottes J., Levis-Williams D., Prehistoryczni szamani. Trans i magia $w$ zdobionych grotach oraz Po „Prehistorycznych szamanach” - polemiki i odpowiedzi, przeł. A. Gronowska, wstęp M. Ryszkiewicz, Warszawa 2009

Driewnietjurskije mify. Po knigie O. Markowoj i K. Żanabajewa „Zołotaja kołybiel”, $<$ http://bibliotekar.kz/kazahskaja-literatura-hrestomatija-za-6-/tengri-i-umai. html>, dostęp: 7.03.2021

Drury N., Szamanizm, przeł. H. Smagacz, Poznań 1994

Dżusupdżan Dż., Dalekoje echo szamana ili kamłanije po-kyrgyzskij, <https:// rus.azattyk.org/a/kyrgyzstan_kamlanie_jusupjan/24361279.html>, dostęp: 5.03.2021

Eliade M., Sacrum, mit, historia, przeł. A. Tatarkiewicz, Warszawa 1974

Eliade M., Sacrum a profanum: o istocie sfery religijnej, przeł. B. Baran, Warszawa 2008

Eliade M., Szamanizm i archaiczne techniki ekstazy, przeł. i wstęp K. Kocjan, oprac. naukowe J. Tulisow, Warszawa 1994

Eliade M., Traktat o historii religii, przeł. J. Wierusz-Kowalski, wstęp L. Kołakowski, Łódź 1993

Jelizawieta Stiszowa - o swojem fil'mie, sniatom w Kyrgystanie, <https://www.golosameriki.com/a/oleg-sulkin-suleiman-mountain-of-elizaveta-stishova/5046975. html>, dostęp: 1.03.2021.

Łabenda M., Dolina Fergańska w czasach islamu, Warszawa 2016

Nikołajewa D.A., Żenskoje bożestwo $w$ tradicionnoj kulturie buriat priedbajkalia, „Izwiestija Rossijskogo Gosudarstwiennogo Pedagogiczeskogo Uniwiersiteta imienija A.I. Gierciena" 2010, nr 123, s. 245-255

Prokofiew W., „Suliejman Gora” - oswieżajuścieje postpostimperskoje road-movie iż Kirgizii, „Cinema Art”, 2018, nr 11/12, <https://kinoart.ru/reviews/suleyman-gora-osvezhayuschee-postpostimperskoe-road-muvi-iz-kirgizii>, dostęp: 2.03.2021

Sztuka naskalna i szamanizm Azji Środkowej, red. A. Rozwadowski, M.M. Kośko, T.A. Dowson, Warszawa 1999

Szyjewski A., Szamanizm, Kraków 2005

Wyżyński A., Filmy drogi, „Iluzjon” 1990, nr 3-4, s. 11-17 